\title{
Clinical Characteristics of Acute Pediatric Neck Infection and Predictive Factors of Abscess Formation
}

\author{
Sung Ho Gong, Yong Jun Choi, Gun Hee Yu, Youn Woo Kim, Joo Hyun Park, and Yun-Sung Lim \\ Department of Otorhinolaryngology-Head and Neck Surgery, Dongguk University College of Medicine, Ilsan Hospital, Goyang, Korea
}

\section{소아 경부 감염의 임상 양상과 농양 형성의 예측 인자}

공성호 · 최용준 · 유건희 · 김윤우 · 박주현 · 임윤성

동국대학교 의과대학 일산병원 이비인후-두경부외과학교실

Received July 29, 2016

Revised October 25,2016

Accepted October 31, 2016

Address for correspondence

Yun-Sung Lim, MD, PhD

Department of Otorhinolaryngology-

Head and Neck Surgery,

Dongguk University

College of Medicine, Ilsan Hospital,

27 Dongguk-ro, Ilsandong-gu,

Goyang 10326, Korea

Tel $+82-31-961-7439$

Fax $+82-31-961-7427$

E-mail yslim0503@gmail.com
Background and Objectives Abscess of neck is a life-threatening disease in children. Detection of abscess is important because it is essential for the determination of surgical drainage. However, clinical diagnosis is difficult, because children are seldom able to verbalize their symptoms or cooperate with physical examination. This study aims to review the clinical characteristics of 157 pediatric patients with neck inflammation and investigate the relative risk factors for abscess.

Subjects and Method Pediatric patients who were admitted to Dongguk University Hospital from January 2005 to July 2014 with acute neck inflammation were reviewed. All 157 pediatric patients were divided into two groups, based on radiologic findings with and without neck abscess.

Results Of 157 patients, 53 children were diagnosed with neck abscess, and peritonsillar abscess was the most common type of neck abscess followed by submandibular abscess, retro - parapharyngeal abscess and posterior triangle \& other abscess. The dominant pathogens, staphylococcal infection $(\leq 2 \mathrm{yr})$ and streptococcal infection $(>3 \mathrm{yr})$, was different for the different age group. The abscess group except for peritonsillar abscess was characterized by younger age, higher heart rate and WBC count, and longer hospital days than those without abscess $(p=0.026,0.026,<0.001,0.007$ respectively). Multivariate analysis revealed younger age $(\leq 24 \mathrm{mo})$ and higher heart rate were independent predictors for abscess formation (odds ratio: $3.022,2.923)$.

Conclusion Pediatric patients with high heart rate \& younger age are at risk for abscess formation; meticulous care and early imaging work up are required in younger children with deep neck infection, and especially with higher heart rate.

Korean J Otorhinolaryngol-Head Neck Surg 2017;60(2):76-82

Key Words Abscess - Deep neck infection - Heart rate $\cdot$ Pediatric.
서 론

상부 호흡기 점막을 통해 병원체가 침투하면 부비동염, 인 후두염, 편도선염 등이 발생한다. 침투한 병원체들이 림프관 을 통해 심경부공간과 근막층의 해부학적 공간으로 전파되 면 봉와직염이나 심경부공간의 감염으로 확장되며 심경부 농 양으로 악화될 수 있다. 또한 심경부 감염은 중요한 기관들이
밀집되어 있는 경부의 특성상 호흡 폐쇄, 경정맥 혈전증, 경동 맥류, 경동맥 파열 및 종격동염과 같은 위험한 합병증이 발생 할 수 있다.

소아에서의 심경부 감염과 농양은 점차 그 발생빈도가 늘 어가는 추세이다.1) 특히 소아 환자는 본인의 증상을 말로 표 현하기 힘들고, 신체검진에 협조가 되지 않는 경우가 많아 그 진단과 치료에 어려움이 있다. 이로 인해 상대적으로 초음파 
및 $\mathrm{CT}$ 등의 영상학적 검사의 의존성이 증가하며, 불필요한 검사가 반복적으로 시행되어 과다한 방사선 노출이나 비용 이 발생할 수 있다. 반대로 영상학적 검사의 거부 혹은 검사가 불가능한 경우 진단과 치료가 늦어짐으로 인하여 합병증이 발 생할 수 있다.

이에 저자들은 소아에서의 경부 감염의 임상 양상과 치료 결 과에 대해 알아보고 나아가 심경부 농양의 임상 양상과 농양 형 성을 예측할 수 있는 임상 지표들에 대해 알아보고자 하였다.

\section{대상 및 방법}

2005년부터 2014년까지 경부 감염 및 이로 인한 임상 증상 으로 심경부 농양이 의심되어 경부 컴퓨터단층촬영검사 및 경 부 초음파검사를 통해 농양의 유무를 확인한 환자들 중 본 원에서 입원치료를 시행받은 1 개월에서 15 세까지의 소아들 157 명을 대상으로 하였다. 해당 환자들은 보존적 치료로 광범위 항생제의 정맥투여(ampicillin+sulbactam 또는 3rd cephalosporins+metronidazole)를 기본으로 시행하였으며 2일간 격으로 시행한 $\mathrm{CBC}$ 와 $\mathrm{CRP}$ 수치의 상승 혹은 증상과 신체검 진상 악화를 기준으로 추가적인 영상의학 검사를 시행하였다. 영상검사상 농양의 여부는 clear central hypodensity, clear ring enhancement, scalloping of abscess wall 소견을 기준 (Fig. 1)으로 하여 영상의학과 전문의에 의해 판독되었다. 비 정규시간 및 응급상황의 경우 이비인후과 전문의의 소견으 로 농양 유무를 확인하여 필요할 경우 절개배농이나 흡인 배 농을 시행하였다. 의무기록을 후향적으로 조사하여 성별 및 연령 분포와 함께 혈액검사 결과로 백혈구 수치와 C-반응단 백, 호중구 비율, 절대호중구 수치 등과 활력징후 및 항생제
사용력, 입원 기간 등을 비교 분석하였다. 이를 바탕으로 나이 및 농양 위치에 따른 편도농양(peritonsillar abscess, PTA) 및 비-편도농양(non-PTA)군으로 나누어 조사하였다. 비농 양군(non-abscess group)은 수차례의 영상검사 모두에서 최 종적으로 농양이 확인되지 않은 환자들의 자료를 수집하였 다. 활력징후의 경우 모든 환자에 대해 내원 직후 본원에서 의 치료가 시작되기 전 단계에서 체온과 함께 심박수를 수집 하였다. 소아의 경우 연령별로 심박수의 정상수치와 범위가 달 라 정상 심박수 중간값과의 차이를 구하였다. ${ }^{2}$ 활력징후 중 혈 압의 경우 비침습적 방법으로는 영·유아에서 정확한 혈압 측 정이 어려워 자료수집에 포함하지 않았다.

비농양군과 각 농양군들 간에 대한 통계분석은 t-test를 입원 기간과 다른 인자들과의 관련성에 대해서는 Spearman's correlation test를 사용하였다. 농양 형성의 예측 인자를 확 인하기 위하여 각 인자들과 농양 간의 연관성 분석을 위해 logistic regression을 사용하였다. 통계분석 프로그램은 Statistical Package for the Social Sciences(SPSS version 12.0; SPSS Inc., Chicago, IL, USA) 프로그램을 이용하였고, 유의 수준은 0.05 미만으로 하였다.

\section{결 과}

\section{성별과 연령 분포}

전체 157예 중 남녀의 비는 남아 74예(47\%), 여아 83예(53\%) 였고, 연령 분포는 1 개월부터 15 세로 평균 연령은 $6.4 \pm 4.5$ 세였 다. 이 중 53예(33.7\%)에서 심경부 농양으로 영상학적 검사를 통한 확진이 되었으며 5세 이하가 84예 중 24예(29\%), 6세에서 10 세가 37예 중 9예(24\%), 11세 이상이 36예 중 20예(56\%)였다.
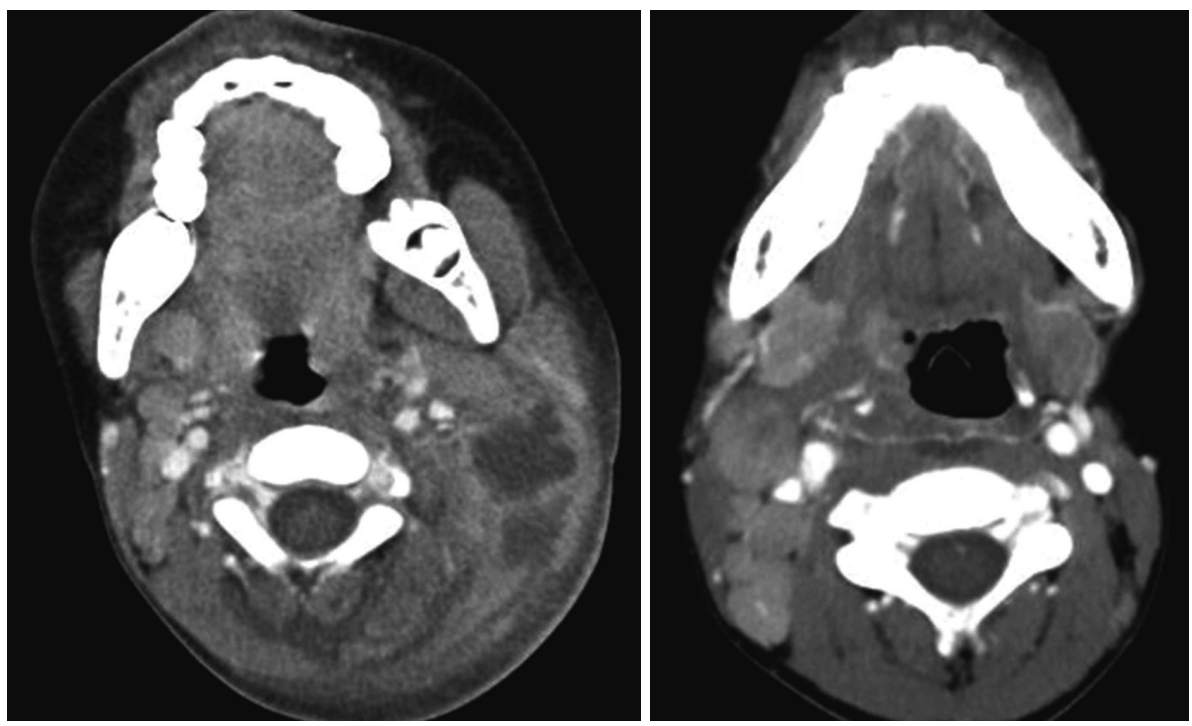

Fig. 1. Axial imaging of contrast neck CT with and without neck abscess. According to finding about 'clear central hypodensity', 'clear ring enhancement', 'scalloping of abscess wall' findings were determined neck abscess on the neck CT. 
Table 1. Clinical differences between abscess group and non-abscess group

\begin{tabular}{lccc}
\hline & Abscess group $(\mathrm{n}=53)$ & Non-abscess group $(\mathrm{n}=104)$ & $\mathrm{p}$-value \\
\hline Age $($ mean years) & $7.4 \pm 5.4$ & $5.8 \pm 3.8$ & 0.032 \\
WBC count (mean value, $\left./ \mathrm{mL}^{3}\right)$ & $17211 \pm 6840$ & $13001 \pm 6827$ & $<0.01$ \\
C-reactive protein level $($ mean value) & $6.08 \pm 4.78$ & $5.70 \pm 6.15$ & 0.705 \\
Heart rate $\Delta$ & $25.1 \pm 17.8$ & $22.6 \pm 11.6$ & 0.306 \\
Body temperature $\left({ }^{\circ} \mathrm{C}\right)$ & $38.1 \pm 0.96$ & $38.5 \pm 0.91$ & 0.012 \\
Neutrophil percentage (\%) & $69.6 \pm 15.3$ & $61.4 \pm 21.2$ & 0.015 \\
Absolute neutrophil count & $12026 \pm 5379$ & $8549 \pm 6071$ & 0.001 \\
Days of previous antibiotics (mean value) & $2.9 \pm 3.5$ & $3.8 \pm 5.9$ & 0.319 \\
Hospital day & $8.1 \pm 4.8$ & $7.3 \pm 5.3$ & 0.383 \\
\hline
\end{tabular}

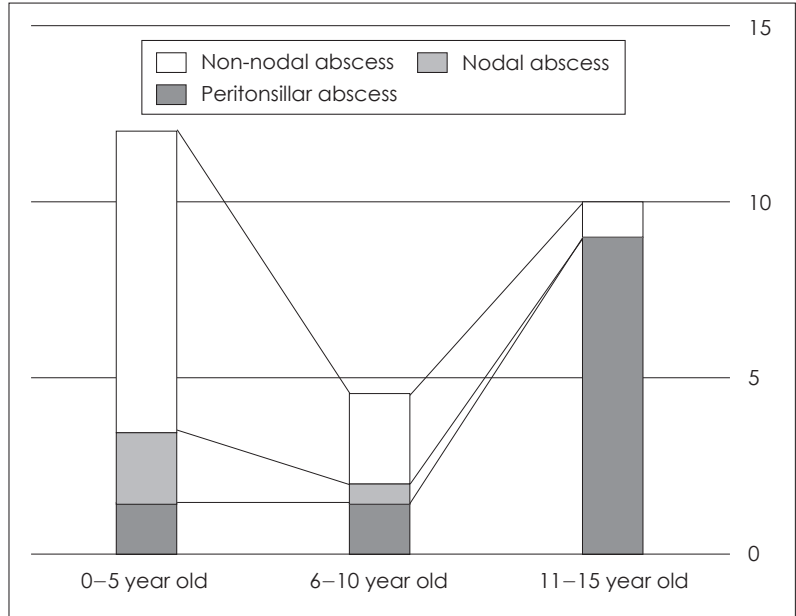

Fig. 2. Different type of abscesses according to age group. Comparing the difference between the abscess formation sites according to age, increasing age is associated with the increase in peritonsillar abscess and the decrease in lymph node abscess.

\section{입원 기간}

내원 전 평균 항생제 사용 기간은 평균 3.2일이었으며(0 30 일), 평균 재원기간은 7.6일(3 50일)이었다. 농양의 유무에 따 라 8.1일 및 7.3일, 수술적 치료의 유무에 따라 8.31일 및 7.3 일로 차이를 보였다. 그러나 평균비교를 시행한 결과 농양의 존재 및 수술 시행의 경우 입원 기간과의 통계적으로 유의한 경향을 보이지는 않았다. 연령에 따라 어릴수록 재원기간이 유의미하게 긴 모습 $(r=-0.253)$ 을 관찰할 수 있었다.

\section{임상병리검사 소견}

입원당시 시행한 말초혈액검사상 백혈구 수치는 14423/ $\mathrm{mL}^{3}$ (1880 42370)였으며, 호중구 비율은 65.0\%(9.4 92.3)였 다. 절대호중구 수치는 9723(1020 33740)이었으며 C-반응단 백 수치는 5.84(0.01 32.29)였다. 백혈구 수치가 $10000 / \mathrm{mL}^{3}$ 이 상인 환자가 157 예 중 113예(72\%)였으며, 그중 $15000 / \mathrm{mL}^{3}$ 이 상인 경우가 71예(45\%), 20000/mL 이상인 경우도 33예(21\%) 를 확인할 수 있었다.

농양이 발생한 환자에서는 혈액검사상 백혈구 수치가 평균
$17211.89 / \mathrm{mL}^{3}$ (3450 35480)였다. $15000 / \mathrm{mL}^{3}$ 이상인 경우가 53예 중 48예(91\%)였으며, 이는 비농양군(62\%)에 비해 높은 비 율을 보였으며 통계적으로도 유의함을 확인할 수 있었다. 호 중구 비율은 69.5\%(38 91.3)였으며 절대호중구 수치는 12026.6 (1830 25950)이었다. 이 역시 비농양군에 비해 유의미하게 높 았다. C-반응단백 수치는 6.09(0.04 19.35)였으며 농양의 형성 유무에 따른 통계적인 유의성은 없었다(Table 1).

\section{발생 부위}

초음파 및 $\mathrm{CT}$ 검사에서 측정된 농양의 최대 단면적은 평균 $247 \mathrm{~mm}^{2}(14$ 874)였다. 심경부 농양의 발생 부위는 편도주위 공간 24예(45.3\%), 하악하공간 10예(18.9\%), 후인두·부인두 공간 6예(11.3\%), 후삼각공간 및 기타공간 13예(24.5\%) 순서 였다. 연령에 따른 발생 부위의 차이를 보았을 때 연령이 증 가함에 따라 림프절에서 발생한 농양의 비율이 감소하며 편도 주위 농양이 늘어나는 모습이 관찰되었다(Fig. 2).

편도주위 농양(PTA)과 비-편도주위 농양(non-PTA)을 비 교해 보면 평균 연령은 PTA에서 11.3세로 non-PTA의 3.9세 와 유의미한 차이를 보였다. PTA의 경우 남녀의 비율이 10:14 로 여자가 흔하였으나 non-PTA의 경우 남녀 비율이 14:15로 유사하였다. 활력징후는 유의미한 차이를 보이지 않았으나 임 상병리검사 결과를 비교해 볼 때, non-PTA에서의 백혈구 수 치가 $19001 / \mathrm{mL}^{3}$ 로 PTA의 백혈구 수치 $15208 / \mathrm{mL}^{3}$ 에 비해 유의하게 $(p-$ value $=0.043)$ 높았으며 호중구 비율은 PTA에서 $75.7 \%$ 와 non-PTA에서 64.1\%로 유의하게 $(p-$ value $=0.005)$ 낮 았다. 입원 기간 또한 PTA에서 5.3일과 non-PTA에서 10.6일 로 유의미하게 $(p-$ value $=0.000)$ 긴 모습을 관찰할 수 있었다.

\section{활력징후}

내원 직후 본원에서의 치료가 시작되기 전 시행한 활력징후 검사상 전체 157 예 중 16 예에서 빈맥을 확인할 수 있었으며, 각 군에서의 빈맥의 비율은 전체 농양군 53예 중 12예에서, 비 농양군 104예 중에서는 4예에서 빈맥을 확인할 수 있었다. 연 
Table 2. Clinical features of abscess group (excluding peritonsillar abscess)

\begin{tabular}{lccc}
\hline & Abscess group (excluding PTA) $(\mathrm{n}=29)$ & Non-abscess group $(\mathrm{n}=104)$ & $\mathrm{p}$-value \\
\hline Age (mean years) & $4.0 \pm 4$ & $5.8 \pm 3.8$ & 0.026 \\
WBC count (mean value, $\left./ \mathrm{mL}^{3}\right)$ & $19121 \pm 7771$ & $13001 \pm 6827$ & $<0.01$ \\
C-reactive protein level (mean value) & $6.2 \pm 5.25$ & $5.70 \pm 6.15$ & 0.693 \\
Heart rate $\Delta$ & $28.7 \pm 16.4$ & $22.6 \pm 11.6$ & 0.026 \\
Body temperature $\left({ }^{\circ} \mathrm{C}\right)$ & $38.2 \pm 1.02$ & $38.5 \pm 0.91$ & 0.197 \\
Neutrophil percentage (\%) & $64.3 \pm 22.3$ & $61.4 \pm 21.2$ & 0.516 \\
Absolute neutrophil count & $12614 \pm 5894$ & $8549 \pm 6071$ & 0.002 \\
Days of previous antibiotics (mean value) & $2.8 \pm 3.4$ & $3.8 \pm 5.9$ & 0.289 \\
Hospital day & $10.4 \pm 4.2$ & $7.3 \pm 5.3$ & 0.007 \\
\hline
\end{tabular}

PTA: peritonsillar abscess

Fig. 3. Flow of patients according to diagnosis, surgical management and treatment outcome. Initial imaging showed abscess formation in 47 cases out of a total of 157 cases. Following imaging was carried out according to clinical features and 7 cases showed new abscess formation. Out of 54 cases diagnosed of abscess, 8 cases were cured with conservative treatment. Ultrasound guided aspiration was carried out in 4 cases. 3 cases showed improvement. One showed no improvement after repetitive aspiration. Incision and drainage was performed in 43 cases.

령별 정상 심박수와의 차이를 비교한 결과, 정상치와의 차이 값은 전체 농양군에서 25.1, non-PTA군에서 28.7, 비농양군 에서 22.6으로 non-PTA군과 비농양군 간의 유의한 차이 $(p=0.026)$ 를 관찰할 수 있었다. 전체 환자의 평균 체온은 $38.3 \pm 0.9^{\circ} \mathrm{C}(36.6 \sim 40.3)$ 였고, 농양이 확인된 환자들의 평균 체온은 $38.1 \pm 1.0^{\circ} \mathrm{C}(36.7 \sim 40.3)$ 로 확인되지 않은 환자들의 평 균 체온 $38.5 \pm 0.9^{\circ} \mathrm{C}(36.6 \sim 40.2)$ 에 비해 유의하게 낮았으나 $(p=0.012)$, 평균 체온 $37.9^{\circ} \mathrm{C}$ 의 $\mathrm{PTA}$ 환자들을 제외한 non$\mathrm{PTA}$ 군과 비농양군을 비교하였을 때 유의한 차이를 보이지 는 않았다 $(p>0.05)$ (Table 2).

\section{치료 결과}

전체 157예 중 초기 영상검사 결과 46예(29\%)에서 농양을 확인하였으며 임상 양상에 따른 추가적인 영상학적 검사에서 새롭게 농양이 형성된 7예를 확인하였다. 농양이 발생된 53 예 중 8예에서는 보존적 치료 이외의 추가적인 처치 없이 완치 되었고 초음파 유도하 흡인 배농을 시행한 4예 중 3예는 호전 되었으나 반복적인 흡인에도 호전을 보이지 않는 1 예를 포함 하여 42예에서 절개배농술을 시행하였다(Fig. 3). 농양의 크
기에 따라 $200 \mathrm{~mm}^{2}$ 이하의 환자 28 명과 이상의 환자 25 명을 비교하였을 때, 보존적 치료만으로 호전된 비율이 각각 7명 (25\%)과 1명(4\%)으로 유의한 차이를 보였다. 또한 $200 \mathrm{~mm}^{2}$ 이 상에서만 수술 이후의 재발로 인하여 추가적인 절개배농을 시행한 3예가 있었고, 술후 기도관리를 위해 기관삽관을 유지 한 채 중환자실 치료가 필요하였던 2예가 있었으나, 전체 환자 들 모두 합병증 없이 퇴원하였다.

\section{농양의 세균배양 검사 결과}

본 연구에서 세균배양 검사를 시행한 32예 중 7예를 제외한 25 예에서 균이 검출되었고 그중 오염이 의심된 1 예를 제외한 24예 중 포도상구균이 9예(methicillin resistant 2예, methicillin sensitive 7예)였다. 연쇄상구균 15예 중 Streptococcus pyogenes 5예, Streptococcus not groupable 7예, Streptococcus group C 1예, Streptococcus group C와 F의 동반 1예, Streptococcus pyogenes와 not groupable의 동반 1예가 동정 되었다. 혐기성균의 경우 술전 항생제 사용 및 검체 채취와 운 반 과정에서의 노출 등으로 인하여 동정되지 않은 경우가 있 을 것으로 판단된다. 나이에 따라 농양의 세균배양 검사 결과 
를 분류해 보았을 때 2세 이하에서 포도상구균이 전체 10예 중 7예로 가장 많은 비율을 차지하였으나 3세 이상에서는 전 체 22예 중 2예로 그 비율이 감소하였으며 연쇄상구균이 15 예 로 흔한 원인균이 변화하였다(Fig. 4).

\section{경부 농양 형성과 관련된 하는 임상 지표}

명확하게 차이가 나는 PTA군과 non-PTA군 간의 임상 지 표 간 차이를 반영하고자 심경부 농양의 예측 인자를 분석 할 때 non-PTA군과 비농양군을 평균비교하였다. 평균적으 로 농양이 형성된 군의 나이가 어리고, 백혈구 수치, 심박수, 입원 기간이 더 높거나 커짐을 확인할 수 있었다(Table 2). 이에 대해 다변량 분석을 시행한 결과 35 이상의 높은 심박수(odds ratio: 2.923, $p$-value=0.039)와 어린 연령(odds ratio: 3.022, $p$-value $=0.038$ )이 농양의 형성과 관련된 예측 인자임을 확인 할 수 있었다(Table 3).

\section{고 찰}

심경부 감염은 소아에서 상기도 감염으로 인하여 발생할 수 있는 중요한 합병증들 중 하나이다. 다양한 바이러스들로

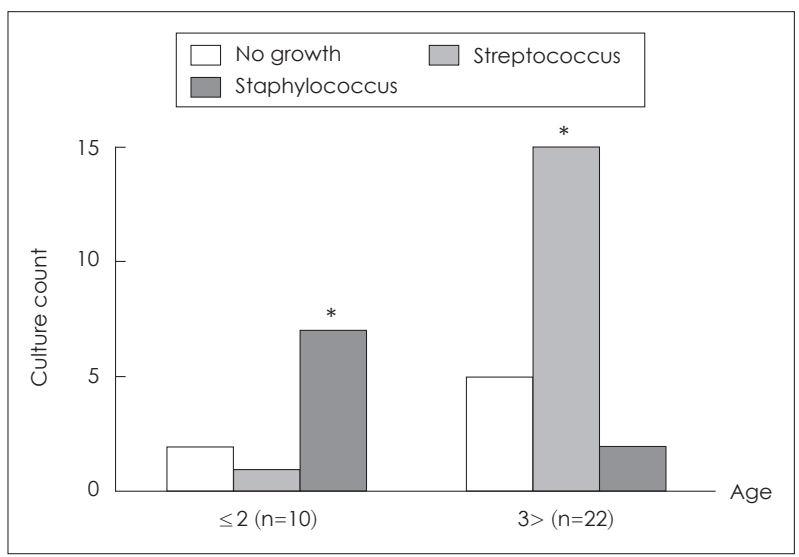

Fig. 4. Different pathogens according to age group. Bacterial culture test results were compared according to age differences. Staphylococcal infection was most common in the under 36 months group, accounting for $70 \%$ of the infections. Staphylococcal infection decreased to $9 \%$ and streptococcal infection increased to $68 \%$ in over 36 month group. This shows that the common pathogen change from staphylococcal infection to streptococcal infection with increasing age. ${ }^{*} p<0.05$.
인하여 상부 호흡기 감염이 호발하며 이와 함께 인후두염, 편 도선염, 비부비동염, 유양돌기염과 같은 세균성 중복감염이 발생하게 된다. 이에 대한 합병증으로 연쇄상구균 및 포도상 구균으로 인한 화농성 염증이 발생한다. 또한 구강, 인후두 의 림프선이 유입되는 경부 림프절은 상기도 감염으로 인하 여 림프절의 비대가 발생하게 되며, 상기도 감염의 빈도가 높 은 소아에서 성인에 비해 림프절 비대 및 이차적 화농성 과정 을 거쳐 심경부 감염이 발생하는 경우가 흔하다. ${ }^{3,4)}$

소아의 경부 농양의 발생 부위로는 편도주위공간을 포함 할 경우 Ungkanont 등5)은 전체 76예의 소아 심경부 농양 환자 중 편도주위공간에서 43예(57\%)의 농양이 발생하여 가장 흔 한 것으로 보고하였다. Dodds와 Maniglia ${ }^{6}$ 도 93예의 소아 심 경부 농양 중 42 예(45\%)에서 편도주위공간 농양이 발생한 것 으로 보고하여 본 연구의 $45.3 \%$ 와 비슷한 비율을 보고하였다.

후인두 농양은 여러 심경부공간들 중 드물게 농양이 형성되 는 공간이나 상대적으로 유아나 어린 아이들에서 흔하게 발 견된다. Yeoh 등ㄱㅇㅣ 보고한 16예의 후인두 농양 환자들은 모 두 6세 이하였으며, 전체 53\%가 1세 이하였다. Kirse와 Rob$\mathrm{erson}^{8)}$ 은 5세 이후 후인두공간 림프절의 화농으로 인한 농 양이 감소하였음을 보고하며 대상군의 연령에 따라 그 비율 이 다르다고 하였다. 그 원인으로 생애 초기 수년 동안 코와 부 비동, 비인두, 인두와 중이에서 후인두 림프절을 통해 활발하 게 배액되나, 5세경 이후부터 점차 후인두공간 림프절이 위 축되기 때문이라 설명하였다. 본 연구에서 연령군별로 발생 위치를 비교해 보았을 때, 후인두와 부인두공간에서는 남아 의 비율이 높았으며, 나이가 증가함에 따라 림프절 농양의 비 율이 감소하며 편도주위 농양의 비율이 증가함을 확인할 수 있었다. 절개 및 배농 이후의 세균배양 검사를 나이에 따라 분류하였을 때, 포도상구균에서 연쇄상구균으로 흔한 원인 균이 변하는 결과 또한 이러한 발생 부위의 변화로 인한 원인 균의 변화로 생각해 볼 수 있다.

심경부 감염은 발생하는 위치에 따라 호소하는 증상이 다 양하며, ${ }^{9}$ 단순 감염과 배농을 필요로 하는 농양의 형성을 정 확하게 구분하기 위하여 영상학적 검사가 필요하다. 일반적 인 경우 초음파검사를 우선적으로 시행하게 되나, 본 연구에 서는 환자의 입원 방법에 따라 초기 검사 방법이 다양하였다.

Table 3. Summary of the multivariate logistic regression analysis with clinical manifestations as risk factors for abscess formation (excluding peritonsillar abscess)

\begin{tabular}{lccc}
\hline & Odds ratio & $95 \% \mathrm{Cl}$ & p-value \\
\hline Age $(\leq 24$ months $)$ & 3.022 & $1.062-8.598$ & 0.038 \\
WBC count $\left(\leq 150000 / \mathrm{mL}^{3}\right)$ & 1.967 & $0.793-4.880$ & 0.144 \\
Heart rate $(\Delta>35)$ & 2.923 & $1.053-8.108$ & 0.039 \\
Gender $($ male $)$ & 0.875 & $0.355-2.153$ & 0.771 \\
\hline
\end{tabular}


외래를 통하여 입원한 환자의 경우 초음파검사를 우선적으 로 시행하는 경우가 대부분이었으나 응급실을 통하여 입원한 환자의 경우 조영 증강 CT 검사를 시행한 경우가 많았다. 하 지만 소아에서는 성인에 비해 문진을 통한 정확한 병력청취 와 신체검진이 힘들어 영상검사의 필요성이 증가한다. 초음파 의 경우 숙련된 검사자가 필요하며, $\mathrm{CT}$ 검사의 경우 방사선 및 조영제 노출과 비용의 문제들로 인하여 검사를 자주 시행 할 수 없기 때문에 농양의 형성을 예측하고자 하는 시도가 지 속되어 왔다. Saluja 등이은 초기 CT에 따른 가이드라인을 제 안하여 배농을 필요로 하는 농양을 예측하고자 하였으나 유 의하지 않은 결과를 보고하였다. Meyer 등ํㅡㄴ 어린 환자에 서 높은 백혈구 수치를 가질수록 농양이 형성되었을 가능성 이 높으며, 증상의 기간은 유의미한 차이를 보이지 못한다고 하였다. 본 연구에서도 기존의 연구와 같이 농양이 형성된 환 자군에서 유의하게 높은 백혈구 수치와 호중구 비율을 확인 할 수 있었다.

소아 심경부 감염의 경우 성인 심경부 감염과 비교하였을 때 보존적 치료만으로 호전될 가능성이 높은 편이라고 알려 져 있다. 기존에 국내에서 보고된 바에 따르면 Lee 등르는 농 양의 직경이 $2 \mathrm{~cm}$ 미만인 경우 보존적 치료만으로 호전된 경 우가 많았다고 기술하고 있다. Lee 등흐는 $2000 \mathrm{~mm}^{2}$ 를 수술 적 치료의 기준으로 삼았었다. 본 논문의 자료에서도 200 $\mathrm{mm}^{2}$ 를 기준으로 하여 구분하였을 때, 이보다 큰 경우 보존 적 치료만으로 회복될 가능성이 낮았다.

저자들은 기존의 소아 심경부 감염 연구에서 포함되지 않 았던 생체 징후를 추가로 수집하여 농양 형성군과 농양이 형 성되지 않은 군을 비교하는 데 이용하였다. 그 결과 상대적으 로 어린 연령과 높은 심박수가 농양 형성과 관련된 예측 인자 임을 확인할 수 있었다. 심박수는 증상을 호소할 수 없는 신 생아들에서 균혈증 및 다른 감염성 질환과 관련된 중요한 인 자 중의 하나로 알려져 있다. ${ }^{14)}$ 최근의 Moorman 등 ${ }^{15)}$ 과 Fairchild 등 ${ }^{16)}$ 의 대규모 무작위 연구 결과들에 따르면 심박수 양 상의 관찰이 균혈증 및 전신적인 염증성 질환의 유무와 수술 적 치료 필요성을 판단하는 데 있어 중요한 역할을 함이 알 려지고 있다. 또한 성인 심경부 농양 환자군을 대상으로 시행 한 Suehara 등 ${ }^{17)}$ 의 연구에서도 빈맥이 조직괴사, 호흡부전, 균혈증과 함께 사망에 이를 수 있는 잠재적인 예후 인자임을 보고한 점을 감안할 때, 환자의 생체 징후 중 심박수는 감염 의 진행과 농양 형성을 예측할 수 있는 인자로 판단된다. 한 편, 농양군에 나타난 평균 $38.1^{\circ} \mathrm{C}$ 의 체온은 비농양군의 평균 $38.5^{\circ} \mathrm{C}$ 와 비교하였을 때 두 군에서 다 열이 있으나 농양군의 체온이 오히려 상대적으로 낮았다. 이는 영상검사를 시행한 입원 환자를 대상으로 한 후향적 연구임을 고려해 볼 때, 농
양이 형성되지는 않았으나 경부 임파선감염을 포함하는 전 신적인 감염이 병발된 상태에서 입원 및 영상검사를 진행한 경우들이 비농양군에서의 상대적으로 높은 발열의 원인일 수 있을 것으로 판단된다. 이를 통해 본 연구에서 생체 징후 중 고 열은 심경부 농양의 형성을 예측하는 데 상대적으로 제한이 있었다.

본 연구는 입원 환자군을 통한 후향적 연구로 인해 제한점 이 있을 것으로 판단된다. 그러나 기존의 소아 심경부 농양의 연구에서 포함되지 않았던 생체 징후를 포함하여 비교하였 다. 또한 농양 환자만을 확인한 연구 혹은 전체 소아 환자군 을 단순 비교한 연구들에서 더 나아가 입원 및 영상학적 검 사를 시행해야 할 정도로 농양이 의심되는 주요한 환자들을 대상으로 연구를 진행함으로써 실제 심경부 감염이 의심되는 소아 환자에서의 농양 형성 유무와 관련된 인자를 비교해 볼 수 있었다. 심경부 감염을 의심할 수 있는 2세 이하 소아 환자 에서 높은 심박수가 농양 형성을 예측할 수 있는 인자임을 고 려할 때, 심경부 감염이 발생한 어린 소아에서 빈맥이 있는 경 우 농양의 발생에 대한 적극적인 영상학적 검사와 치료에 주 의를 기울여야 할 것으로 판단한다.

\section{REFERENCES}

1) Cabrera CE, Deutsch ES, Eppes S, Lawless S, Cook S, O’Reilly RC, et al. Increased incidence of head and neck abscesses in children. Otolaryngol Head Neck Surg 2007;136(2):176-81.

2) Davignon A, Rautaharju P, Boisselle E, Soumis F, Mégélas M, Choquette A. Normal ECG standards for infants and children. Pediatr Cardiol 1980;1(2):123-31.

3) Wright NL. Cervical infections. Am J Surg 1967;113(3):379-86.

4) Gidley PW, Ghorayeb BY, Stiernberg CM. Contemporary management of deep neck space infections. Otolaryngol Head Neck Surg 1997; 116(1):16-22.

5) Ungkanont K, Yellon RF, Weissman JL, Casselbrant ML, GonzálezValdepeña $\mathrm{H}$, Bluestone $\mathrm{CD}$. Head and neck space infections in infants and children. Otolaryngol Head Neck Surg 1995;112(3):375-82.

6) Dodds B, Maniglia AJ. Peritonsillar and neck abscesses in the pediatric age group. Laryngoscope 1988;98(9):956-9.

7) Yeoh LH, Singh SD, Rogers JH. Retropharyngeal abscesses in a children's hospital. J Laryngol Otol 1985;99(6):555-66.

8) Kirse DJ, Roberson DW. Surgical management of retropharyngeal space infections in children. Laryngoscope 2001;111(8):1413-22.

9) Elsherif AM, Park AH, Alder SC, Smith ME, Muntz HR, Grimmer F. Indicators of a more complicated clinical course for pediatric patients with retropharyngeal abscess. Int J Pediatr Otorhinolaryngol 2010;74(2):198-201.

10) Saluja S, Brietzke SE, Egan KK, Klavon S, Robson CD, Waltzman ML, et al. A prospective study of 113 deep neck infections managed using a clinical practice guideline. Laryngoscope 2013;123(12): 3211-8.

11) Meyer AC, Kimbrough TG, Finkelstein M, Sidman JD. Symptom duration and CT findings in pediatric deep neck infection. Otolaryngol Head Neck Surg 2009;140(2):183-6.

12) Lee DW, Lee HS, Lee KY, Park IB, Park CW, Tae K. A clinical study of deep neck infection in children. Korean J Otolaryngol-Head Neck Surg 2005;48:1382-7. 
13) Lee JK, Kim HD, Yoon TM, Lee DH, Kim G, Seo KS, et al. Characteristics of deep neck infections in pediatric patients compared with adults. Korean J Otolaryngol-Head Neck Surg 2007;50(2):161-5.

14) Yapıcıŏlu H, Özlü F, Sertdemir Y. Are vital signs indicative for bacteremia in newborns? J Matern Fetal Neonatal Med 2015;28 (18):2244-9.

15) Moorman JR, Carlo WA, Kattwinkel J, Schelonka RL, Porcelli PJ, Navarrete CT, et al. Mortality reduction by heart rate characteristic monitoring in very low birth weight neonates: a randomized trial. J
Pediatr 2011;159(6):900-6.

16) Fairchild KD, Schelonka RL, Kaufman DA, Carlo WA, Kattwinkel $\mathrm{J}$, Porcelli PJ, et al. Septicemia mortality reduction in neonates in a heart rate characteristics monitoring trial. Pediatr Res 2013;74(5): $570-5$.

17) Suehara AB, Gonçalves AJ, Alcadipani FA, Kavabata NK, Menezes MB. Deep neck infection: analysis of 80 cases. Braz J Otorhinolaryngol 2008;74(2):253-9. 